Article

\title{
tert-Butylphenolic Derivatives from Paenibacillus odorifer-A Case of Bioconversion
}

\author{
Thi-Bach-Le Nguyen ${ }^{1}$, Olivier Delalande ${ }^{2}$, Isabelle Rouaud ${ }^{1}$, Solenn Ferron ${ }^{1}$, Laura Chaillot ${ }^{3}$, \\ Rémy Pedeux ${ }^{3}$ and Sophie Tomasi ${ }^{1, *}$ \\ 1 University of Rennes 1, CNRS, ISCR-UMR 6226, F-35000 Rennes, France; \\ nguyen.bachle@yahoo.com (T.-B.-L.N.); isabelle.rouaud@univ-rennes1.fr (I.R.); \\ solenn.ferron@univ-rennes1.fr (S.F.) \\ 2 University of Rennes 1, CNRS, IGDR-UMR 6290, F-35000 Rennes, France; \\ olivier.delalande@univ-rennes1.fr \\ 3 Chemistry, Oncogenesis, Stress, Signaling, Centre Eugène Marquis, Université de Rennes 1, INSERM U1242, \\ 35000 Rennes, France; laura.chaillot@univ-rennes1.fr (L.C.); remy.pedeux@univ-rennes1.fr (R.P.) \\ * Correspondence: sophie.tomasi@univ-rennes1.fr; Tel.: +33-223-234-817
}

Received: 14 June 2018; Accepted: 28 July 2018; Published: 5 August 2018

\begin{abstract}
Two compounds (1) and (2) containing tert-butylphenol groups were, for the first time, produced during the culture of Paenibacillus odorifer, a bacterial strain associated with the crustose lichen, Rhizocarpon geographicum. Their entire structures were identified by one-dimensional (1D) and two-dimensional (2D) NMR and high-resolution electrospray ionisation mass spectrometry (HRESIMS) spectroscopic analyses. Among them, Compound 1 exhibited significant cytotoxicity against B16 murine melanoma and $\mathrm{HaCaT}$ human keratinocyte cell lines with micromolar half maximal inhibitory concentration $\left(\mathrm{IC}_{50}\right)$ values. Furthermore, after supplementation studies, a putative biosynthesis pathway was proposed for Compound $\mathbf{1}$ throughout a bioconversion by this bacterial strain of butylated hydroxyanisole (BHA), an antioxidant polymer additive.
\end{abstract}

Keywords: tert-butylphenols; Paenibacillus odorifer; Rhizocarpon geographicum; bioconversion

\section{Introduction}

Organic products with branched tert-butyl groups represent a relatively important number of active compounds [1,2]. In the past, this group was already exploited in many organic syntheses due to its chemical reactivity. There are more than 200 compounds containing tert-butyl groups, described as natural products with interesting bioactivities [3]. Indeed, the tert-butyl moiety can be found in a variety of compounds produced by various sources, such as plants, fungi, algae, cyanobacteria [4-9], and especially from bacteria which were admitted as a source of novel and interesting bioactive products [10]. The tert-butylated compounds from natural sources reported in these papers often belong to classes of terpenes or polyketides. Although metabolites containing tert-butyl functionality on the aromatic ring are considered to be rare, several tert-butylphenyl derivatives were already isolated from organisms and they also exhibited remarkable antitumor, antibacterial, and antioxidant activities [11-13]. Chemical studies on Paenibacillus odorifer, a bacterium associated with the crustose lichen, Rhizocarpon geographicum, led to the identification of two tert-butylphenol derivatives $(\mathbf{1}, \mathbf{2})$ described in Figure 1. Interestingly, aromatic compounds simultaneously bearing a tert-butyl group and a sulfur atom are really uncommon in nature. The aims of this work were to characterize these compounds, to give some hypothesis about their origin, and to evaluate their cytotoxic activities. Herein, to our knowledge, is the first report of the bacterial production of Compound $\mathbf{1}$ carrying a tert-butyl phenol moiety and a sulfur atom. 

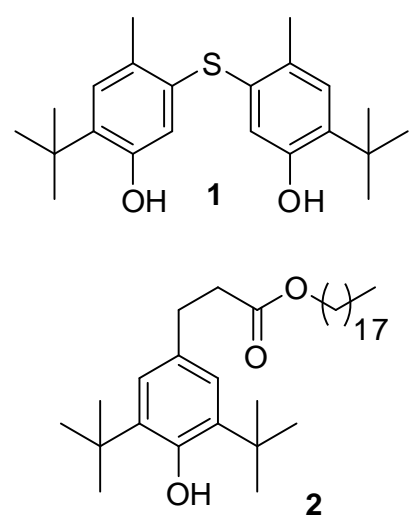

Figure 1. The structure of tert-butylphenolic derivatives found in the culture of Paenibacillus odorifer.

\section{Results}

\subsection{Process of Purification}

Paenibacillus odorifer (P. odorifer) was cultivated via a scale-up $(4.0 \mathrm{~L})$ shaken fermentation at $25{ }^{\circ} \mathrm{C}, \mathrm{pH} \mathrm{7,} 120 \mathrm{rpm}$ with 1\% (v/v) inoculum in GYM Streptomyces medium supplemented with $\mathrm{CaCO}_{3}$. From the broth, the excreted metabolites were collected using Amberlite ${ }^{\circledR}$ XAD-7-HP resin, and the resulting extract was separated via a combination of liquid/liquid extraction and normal-phase flash chromatography to give several fractions. Final purification combining silica gel chromatography, semi-preparative HPLC, and preparative silica thin-layer chromatography (TLC) afforded 5,5'-thiobis(2-tert-butyl-4-methylphenol) (1;5.0 mg) and octadecyl 3-(3,5-di-tert-butyl-4-hydroxyphenyl)propanoate (2; $5.9 \mathrm{mg})$.

\subsection{Structural Elucidation}

Compound 1 was obtained as a white amorphous powder. Its molecular formula was assigned as $\mathrm{C}_{22} \mathrm{H}_{30} \mathrm{O}_{2} \mathrm{~S}$ from the $[\mathrm{M}-\mathrm{H}]^{-}$ion at $m / z 357.1983$ according to high-resolution electrospray ionisation mass spectrometry (HRESIMS) data, and required eight degrees of unsaturation. Its ${ }^{13} \mathrm{C}-\mathrm{NMR}$ data highlighted nine carbon signals, which were classified by Jmod and HSQC analyses as two aromatic methine carbons, four aromatic quaternary carbons, one aliphatic quaternary carbon, and four methyl carbons (Table 1). The lack of coupling between two aromatic protons at $\delta_{\mathrm{H}} 6.56 \mathrm{ppm}$ $(1 \mathrm{H}, \mathrm{s}, \mathrm{H}-6)$ and $7.00(1 \mathrm{H}, \mathrm{s}, \mathrm{H}-3)$ indicated a para-relationship between them, and the existence of a 1,2,4,5-tetrasubstituted phenyl nucleus. The presence of three methyl groups at $\delta_{\mathrm{H}} 1.28(9 \mathrm{H}, \mathrm{s}$, H-9/H-10/H-11) along with their HMBC correlations to a quaternary carbon at $\delta_{C} 34.4$ (C-8) revealed the presence of a tert-butyl group which was one of the substituted groups on the aromatic ring. On the other hand, the ${ }^{13} \mathrm{C}$ shift of $\mathrm{C}-2$ at $\delta_{\mathrm{C}} 134.6$ together with its HMBC correlations with $\mathrm{H}-9 / \mathrm{H}-10 / \mathrm{H}-11$ confirmed the position of the tert-butyl group at C-2. In addition, analysis of the HMBC spectrum exhibiting the correlations from $\mathrm{H}-3$ to $\mathrm{C}-8\left(\delta_{C} 34.4\right), \mathrm{C}-4\left(\delta_{C} 125.5\right), \mathrm{C}-5\left(\delta_{C} 137.8\right)$, and $\mathrm{C}-1\left(\delta_{C} 153.4\right)$ provided the presence of a methyl group at C-4, a hydroxyl group at C-1, and a sulfur-bond at C-5. The latter could also be indicated through the HMBC correlations from the aromatic methyl protons at $\delta_{\mathrm{H}} 2.28(3 \mathrm{H}, \mathrm{s}, \mathrm{H}-7)$ to $\mathrm{C}-4, \mathrm{C}-5$, and C-6 ( $\delta_{\mathrm{C}}$ 118.8). Moreover, HMBC correlations from H-6 to C-1, $\mathrm{C}-2, \mathrm{C}-4$, and C-7 were also observed. Interestingly, NOE correlations between two kinds of protons at $\delta_{\mathrm{H}} 7.00(\mathrm{H}-3)$ and $\delta_{\mathrm{H}} 1.28(\mathrm{H}-9 / \mathrm{H}-10 / \mathrm{H}-11)$ indicated that the tert-butyl group possessed a position close to C-3. The remaining structural assignment of Compound $\mathbf{1}$ (Figure 2) required $\mathrm{C}_{11} \mathrm{H}_{15} \mathrm{O}_{\text {, }}$ which corresponds to the already assigned part of Compound 1. On the basis of molecular formula and HMBC correlations, Compound 1 was suggested to possess a symmetrical structure containing two 1,2,4,5-tetrasubstituted phenyl nuclei which were linked via a sulfur bond This structure is close 
to that of a known synthetic compound Santonox (CAS registry number 96-69-5) 78 (Figure 3). This is the first natural isolation of Compound $\mathbf{1}$.
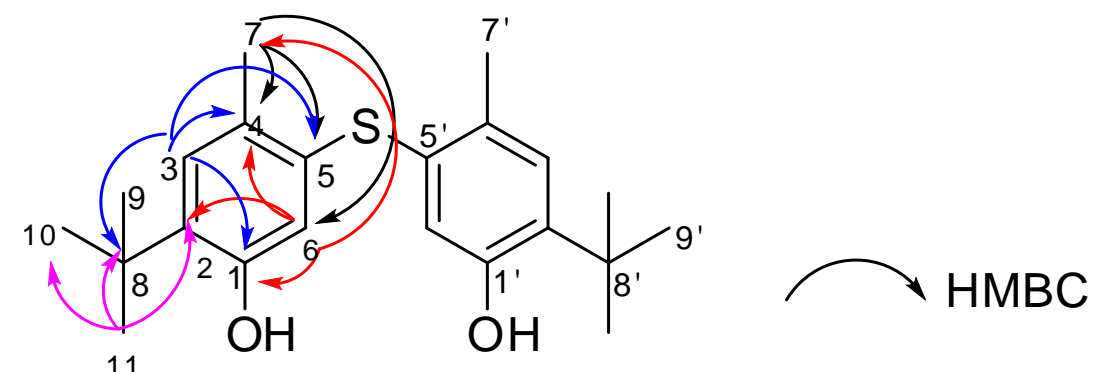

11

Figure 2. Key correlations for the structural assignment of $\mathbf{1}$.<smiles>Cc1cc(C(C)(C)C)c(O)cc1Sc1cc(O)c(C(C)(C)C)cc1I</smiles>

1<smiles>Cc1cc(O)c(C(C)(C)C)cc1Sc1cc(C(C)(C)C)c(O)cc1I</smiles>

Santonox

\section{5,5'-thiobis(2-tert-butyl-4-methylphenol)}

\section{4,4'-thiobis(2-tert-butyl-5-methylphenol)}

Figure 3. Structures of Compound 1 and Santonox.

From the comparison of the NMR spectroscopic data, minor differences in the chemical shifts of protons and carbons were highlighted for Compound $\mathbf{1}$ and standard Santonox. Thus, the identification of the exact structures could not be based on these data, with the exception of NOE correlations. For Santonox, the NOE correlations were clearly displayed between two series of protons at $\delta_{\mathrm{H}} 7.00$ (aromatic proton, $\mathrm{H}-3$ ) and $\delta_{\mathrm{H}} 1.28$ (tert-butyl protons), and at $\delta_{\mathrm{H}} 6.54$ (aromatic proton, $\mathrm{H}-6$ ) and $\delta_{\mathrm{H}} 2.27$ (methyl protons). For Compound 1, the NOE experiments only highlighted the correlations between $\delta_{\mathrm{H}} 7.00$ (aromatic proton, $\mathrm{H}-3$ ) and $\delta_{\mathrm{H}} 1.28$ (tert-butyl protons). The absence of the NOE correlation between $\mathrm{H}-6\left(\delta_{\mathrm{H}} 6.56\right)$ and protons of the tert-butyl group $\left(\delta_{\mathrm{H}} 1.28\right)$ indicated that $\mathrm{H}-6$ in Compound 1 was not close to the tert-butyl group. NOE predictions obtained through molecular dynamics simulations confirmed the NOE experimental data (see Supplementary Materials, Figure S20 and Table S1). As a result, the data from NOE correlations finally highlighted that Compound 1 was an isomer of Santonox. Moreover, to our best knowledge, it is the first report of the isolation of Compound 1 from a bacterial culture. 
Table 1. One-dimensional (1D) and two-dimensional (2D) NMR data for Compound 1 and standard Santonox in $\mathrm{CDCl}_{3}$ (300 $\mathrm{MHz}$ for ${ }^{1} \mathrm{H}-\mathrm{NMR}$, and $75 \mathrm{MHz}$ for $\left.{ }^{13} \mathrm{C}-\mathrm{NMR}\right)$.

\begin{tabular}{|c|c|c|c|c|c|c|c|c|c|c|c|}
\hline \multicolumn{7}{|c|}{ Compound 1} & \multicolumn{5}{|c|}{ Standard Santonox } \\
\hline Position & $\begin{array}{r}\delta_{\mathrm{C}} \\
\mathrm{ppm}\end{array}$ & $\begin{array}{c}\delta_{\mathrm{H}},(\mathrm{ppm}) \\
\text { mult. }(J \text { in } \mathrm{Hz})\end{array}$ & $\begin{array}{l}\text { HMBC } \\
(\mathrm{H} \rightarrow \mathrm{C})\end{array}$ & COSY & NOESY & Position & $\begin{array}{r}\delta_{\mathrm{C}} \\
\mathrm{ppm}\end{array}$ & $\begin{array}{c}\delta_{\mathrm{H}},(\mathrm{ppm}) \\
\text { mult. }(J \text { in } \mathrm{Hz})\end{array}$ & $\begin{array}{l}\text { HMBC } \\
(\mathrm{H} \rightarrow \mathrm{C})\end{array}$ & COSY & NOESY \\
\hline $1 / 1^{\prime}$ & 153.4 & - & - & - & & $1 / 1^{\prime}$ & 153.2 & - & - & - & - \\
\hline $2 / 2^{\prime}$ & 134.6 & - & - & - & & $2 / 2^{\prime}$ & 134.5 & - & - & - & - \\
\hline $3 / 3^{\prime}$ & 130.8 & $7.00, \mathrm{~s}$ & $1,4,5,8$ & $7,9 / 10 / 11$ & $9 / 10 / 11$ & $3 / 3^{\prime}$ & 130.6 & $7.00, \mathrm{~s}$ & $1,4,5,6,7,8$ & $7,9 / 10 / 11$ & $9 / 10 / 11$ \\
\hline $4 / 4^{\prime}$ & 125.5 & - & - & - & & $4 / 4^{\prime}$ & 137.7 & - & - & - & - \\
\hline $5 / 5^{\prime}$ & 137.8 & - & - & - & & $5 / 5^{\prime}$ & 125.4 & - & - & - & - \\
\hline $6 / 6^{\prime}$ & 118.8 & $6.56, \mathrm{~s}$ & $1,2,4,7$ & 7 & & $6 / 6^{\prime}$ & 118.7 & $6.54, \mathrm{~s}$ & $1,4,5,7,8$ & 7 & 7 \\
\hline $7 / 7^{\prime}$ & 19.8 & $2.28, \mathrm{~s}$ & $4,5,6$ & 3,6 & & $7 / 7^{\prime}$ & 19.7 & $2.27, \mathrm{~s}$ & $4,5,6$ & 3,6 & 6 \\
\hline $8 / 8^{\prime}$ & 34.4 & - & & - & & $8 / 8^{\prime}$ & 34.3 & - & - & - & \\
\hline $\begin{array}{c}9,10,11 / 9^{\prime}, 10,11^{\prime} \\
\mathrm{OH}\end{array}$ & 29.7 & $\begin{array}{l}1.28, \mathrm{~s} \\
4.72, \mathrm{br}\end{array}$ & $\begin{array}{c}9 / 10 / 11,2,8 \\
-\end{array}$ & 3 & 3 & $\begin{array}{c}9,10,11 / 9^{\prime}, 10,11^{\prime} \\
\mathrm{OH}\end{array}$ & 29.5 & $1.28, \mathrm{~s}$ & $9 / 10 / 11,2,8$ & 3 & 3 \\
\hline
\end{tabular}


Compound 2 was isolated as a white solid and had a $\mathrm{C}_{35} \mathrm{H}_{62} \mathrm{O}_{3}$ molecular formula determined by the $[\mathrm{M}+\mathrm{Na}]^{+}$peak at $m / z 553.4592$ from its (+)HRESIMS data. The analysis of ${ }^{1} \mathrm{H}-\mathrm{NMR}$ and Jmod, along with HSQC data (Table 2), indicated the presence of two aromatic protons, 19 methylene groups (one of them oxygenated), seven methyl groups (six of them as singlets), four aromatic quaternary carbons, and one carbonyl carbon. The presence of two aromatic protons at $\delta_{\mathrm{H}} 6.99\left(2 \mathrm{H}, \mathrm{s}, \mathrm{H}-3^{\prime} / \mathrm{H}-5^{\prime}\right)$ pointed to the existence of a 1,2,4,6-tetrasubstituted phenyl moiety (Figure 4). Four spin systems could be revealed via analysis of COSY correlations, corresponding to the C-1 to C-2, C- $1^{\prime \prime}$ to C-2",$C-3^{\prime \prime}$ to $\mathrm{C}-17^{\prime \prime}$, and $\mathrm{C}-17^{\prime \prime}$ to $\mathrm{C}-18^{\prime \prime}$ fragments. The HMBC correlations from an exchangeable proton $\left(\delta_{\mathrm{H}} 5.07\right.$, $1 \mathrm{H}, \mathrm{bs})$ to $\mathrm{C}-1^{\prime}$ demonstrated that $\mathrm{C}-1^{\prime}$ might be substituted by a hydroxyl group, and it was confirmed by the ${ }^{13} \mathrm{C}$ shift of $\mathrm{C}-1^{\prime}$ at $\delta_{\mathrm{C}} 152.1$. Compound 2 also presented two tert-butyl groups containing six methyl groups at $\delta_{\mathrm{C} / \mathrm{H}} 30.3 / 1.43\left(18 \mathrm{H}, \mathrm{s}, \mathrm{H}-8^{\prime}, \mathrm{H}-9^{\prime}, \mathrm{H}-10^{\prime}, \mathrm{H}-12^{\prime}, \mathrm{H}-13^{\prime}, \mathrm{H}-14^{\prime}\right)$ connected with two quaternary carbons at $\delta_{\mathrm{C}} 34.3\left(\mathrm{C}-7^{\prime} / \mathrm{C}-11^{\prime}\right)$ as two of the substituted groups on the aromatic ring. In addition, the $\mathrm{HMBC}$ data provided correlations from the protons of tert-butyl groups to C-7 $/ \mathrm{C}-11^{\prime}, \mathrm{C}-2^{\prime} / \mathrm{C}-6^{\prime}\left(\delta_{\mathrm{C}} 135.8\right), \mathrm{C}-3^{\prime} / \mathrm{C}-5^{\prime}\left(\delta_{\mathrm{C}} 124.8\right)$, and C-4 ${ }^{\prime}\left(\delta_{\mathrm{C}} 131.1\right)$; and from H-3' $/ \mathrm{H}-5^{\prime}$ to C-1 $\left(\delta_{C} 152.1\right), C-3^{\prime} / C-5^{\prime}\left(\delta_{C} 124.8\right)$, and $C-1\left(\delta_{C} 31.0\right)$. Moreover, the presence of two coupled methylene groups at $\delta_{\mathrm{H}} 2.85(2 \mathrm{H}, \mathrm{dd}, J=9.1,6.9 \mathrm{~Hz}, \mathrm{H}-1)$ and $\delta_{\mathrm{H}} 2.60(2 \mathrm{H}, \mathrm{dd}, J=9.1,6.9 \mathrm{~Hz}, \mathrm{H}-2)$ was also observed. The HMBC correlations from $\mathrm{H}-1$ to C- $4^{\prime}, \mathrm{C}-3^{\prime} / \mathrm{C}-5^{\prime}, \mathrm{C}-2\left(\delta_{\mathrm{C}} 36.5\right)$, and C-3 ( $\left.\delta_{\mathrm{C}} 173.4\right)$; and from $\mathrm{H}-2$ to $\mathrm{C}-4^{\prime}, \mathrm{C}-1$, and $\mathrm{C}-3$ provided more evidence that this group made a linkage between a phenyl nucleus and a carbonyl carbon (Figure 4). Furthermore, the oxygenated methylene at $\delta_{\mathrm{H}}$ $4.07\left(2 \mathrm{H}, \mathrm{t}, J=6.8 \mathrm{~Hz}, \mathrm{H}-1^{\prime \prime}\right), \delta_{\mathrm{C}} 64.6\left(\mathrm{C}-1^{\prime \prime}\right)$ was linked to carbonyl carbon $\mathrm{C}-3$ and to other several methylene groups as indicated by the HMBC data. Thus, the structure of Compound 2 was established as octadecyl 1-(2',6'-di-tert-butyl-1'-hydroxyphenyl)propanoate, introduced in Figure 4. This structure was already reported in the literature [3]; however, its full NMR data are not yet published, and this is the first report of its isolation from a culture of P. odorifer.

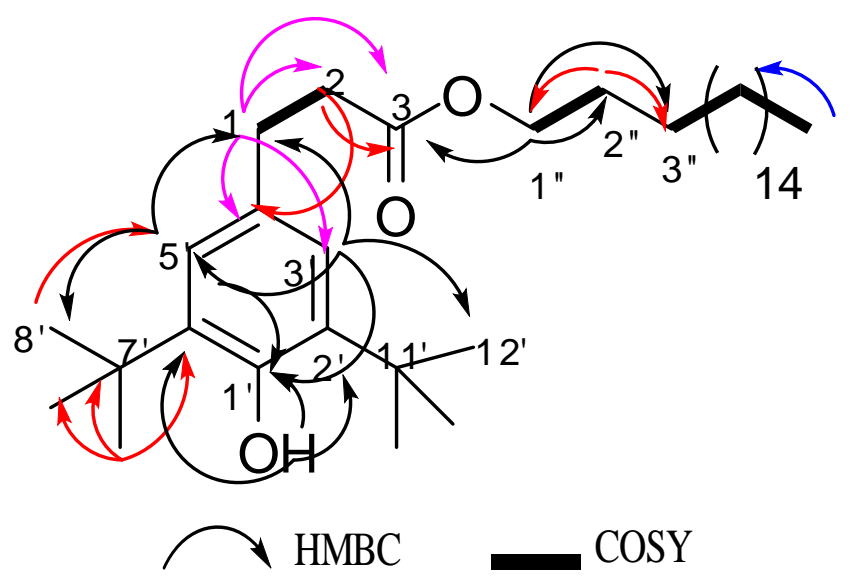

Figure 4. Key correlations for the structural assignment of $\mathbf{2}$. 
Table 2. $1 \mathrm{D}$ and $2 \mathrm{D}$ NMR data for Compound 2 in $\mathrm{CDCl}_{3}\left(300 \mathrm{MHz}\right.$ for ${ }^{1} \mathrm{H}-\mathrm{NMR}$, and $75 \mathrm{MHz}$ for ${ }^{13}$ C-NMR).

\begin{tabular}{|c|c|c|c|c|c|}
\hline \multicolumn{6}{|c|}{ Compound 2} \\
\hline Position & $\delta_{C}$ & Type & $\delta_{\mathrm{H}}$, mult. $(J$ in $\mathrm{Hz})$ & COSY & HMBC $(\mathrm{H} \rightarrow \mathrm{C})$ \\
\hline $1^{\prime}$ & 152.1 & C & - & - & \\
\hline $2^{\prime}$ & 135.8 & $\mathrm{C}$ & - & - & \\
\hline $3^{\prime}$ & 124.8 & $\mathrm{CH}$ & $6.99, \mathrm{~s}$ & & $1^{\prime}, 5^{\prime}, 12^{\prime}$ \\
\hline $4^{\prime}$ & 131.1 & C & - & & \\
\hline $5^{\prime}$ & 124.8 & $\mathrm{CH}$ & $6.99, \mathrm{~s}$ & & $1^{\prime}, 3^{\prime}, 1,8^{\prime}$ \\
\hline $6^{\prime}$ & 135.8 & C & - & & \\
\hline 1 & 31.0 & $\mathrm{CH}_{2}$ & $2.85, \mathrm{dd}(9.1,6.9)$ & 2 & $3^{\prime} / 5^{\prime}, 4^{\prime}, 2,3$ \\
\hline 2 & 36.5 & $\mathrm{CH}_{2}$ & 2.60, dd $(9.1,6.9)$ & 1 & $5^{\prime}, 1,3$ \\
\hline 3 & 173.4 & C & - & & \\
\hline $1^{\prime \prime}$ & 64.6 & $\mathrm{CH}_{2}$ & $4.07, \mathrm{t}(6.8)$ & $2^{\prime \prime}$ & $3,2^{\prime \prime}, 3^{\prime \prime}$ \\
\hline $2^{\prime \prime}$ & 29.7 & $\mathrm{CH}_{2}$ & $1.56-1.61, \mathrm{~m}$ & $1^{\prime \prime}, 3^{\prime \prime}$ & $1^{\prime \prime}, 3^{\prime \prime}$ \\
\hline $3^{\prime \prime}$ & 29.7 & $\mathrm{CH}_{2}$ & $1.56-1.61, \mathrm{~m}$ & $2^{\prime \prime}$ & $2^{\prime \prime}$ \\
\hline $4^{\prime \prime}-17^{\prime \prime}$ & $22.7-32.0$ & $\mathrm{CH}_{2}$ & $1.24, \mathrm{~m}$ & $18^{\prime \prime}$ & $5^{\prime \prime}-17^{\prime \prime}, 2^{\prime \prime}, 3^{\prime \prime}, 18^{\prime \prime}$ \\
\hline $18^{\prime \prime}$ & 14.1 & $\mathrm{CH}_{3}$ & $0.88, \mathrm{t}(6.7)$ & $17^{\prime \prime}$ & $17^{\prime \prime}$ \\
\hline $7^{\prime} / 11^{\prime c}$ & 34.3 & C & - & & \\
\hline $8^{\prime}, 9^{\prime}, 10^{\prime} / 12^{\prime}, 13^{\prime}, 14^{\prime}$ a & 30.3 & $\mathrm{CH}_{3}$ & $1.43, \mathrm{~s}$ & & $8^{\prime}, 9^{\prime}, 10^{\prime} / 12^{\prime}, 13^{\prime}, 14^{\prime}, 7^{\prime} / 11^{\prime}, 2^{\prime}, 6^{\prime}, 3^{\prime} / 5^{\prime}$ \\
\hline $\mathrm{OH}$ & & & 5.07 , bs & & $1^{\prime}, 2^{\prime}, 6^{\prime}$ \\
\hline
\end{tabular}

${ }^{a}$ Carbons $7^{\prime} / 11^{\prime}$ and $8^{\prime}, 9^{\prime}, 10^{\prime} / 12^{\prime}, 13^{\prime}, 14^{\prime}$ form a single peak each.

\subsection{Supplementation Assays}

The structure of Compound $\mathbf{1}$ was determined to be closely related to that of butylated hydroxyanisole (BHA) which is approved as an antioxidant ingredient added to polymers, foods, and food-related products [14-16]. To respond to this issue, a supplementation of the culture of P. odorifer was carried out with standard BHA, put either in a culture flask (a kind of plastic vessel) or in an Erlenmeyer (a kind of glass vessel). Furthermore, the controls were based on the medium incubated in a culture flask and the culture of P. odorifer in an Erlenmeyer flask. The results from the LC-MS data are shown in Figure 5, and they highlighted that both extracts from the cultures supplemented with BHA in the culture flask and Erlenmeyer flask provided $[\mathrm{M}-\mathrm{H}]^{-}$ions at $\mathrm{m} / \mathrm{z} 357$ with a retention time of $35.7 \mathrm{~min}$, which is characteristic of Compound $\mathbf{1}$. However, Compound $\mathbf{1}$ could neither be found in the extract from the medium incubated in the culture flask, nor from the culture of P. odorifer in the Erlenmeyer flask.

Additionally, the analysis of Fraction $\mathbf{1}^{\prime}$, which was a mixture of non-separable BHA and Compound 1, partially purified from the culture supplemented with BHA in the Erlenmeyer flask, showed similar NOE correlations to Compound 1 between $\delta_{\mathrm{H}} 6.99$ and $\delta_{\mathrm{H}} 1.28$ (tert-butyl protons; see Supplementary Materials, Figure S13). Accordingly, we concluded that Compound 1 was converted by P. odorifer from BHA, which was detected in the medium incubated in the culture flask. Therefore, the biosynthetic pathway of Compound 1 is proposed in Figure 6, following the mechanism suggested by Fontecave $[17,18]$ with some modifications. After an oxidative step of BHA, the formed phenoxy radical could react with cysteine as a sulfur donor to produce Compound $\mathbf{1}$ after further reactions. This reaction could be supported by an iron-sulfur cluster protein that was already reported in the genome of P. odorifer (gene symbol PODO_RS22860), described in the NCBI bank. 

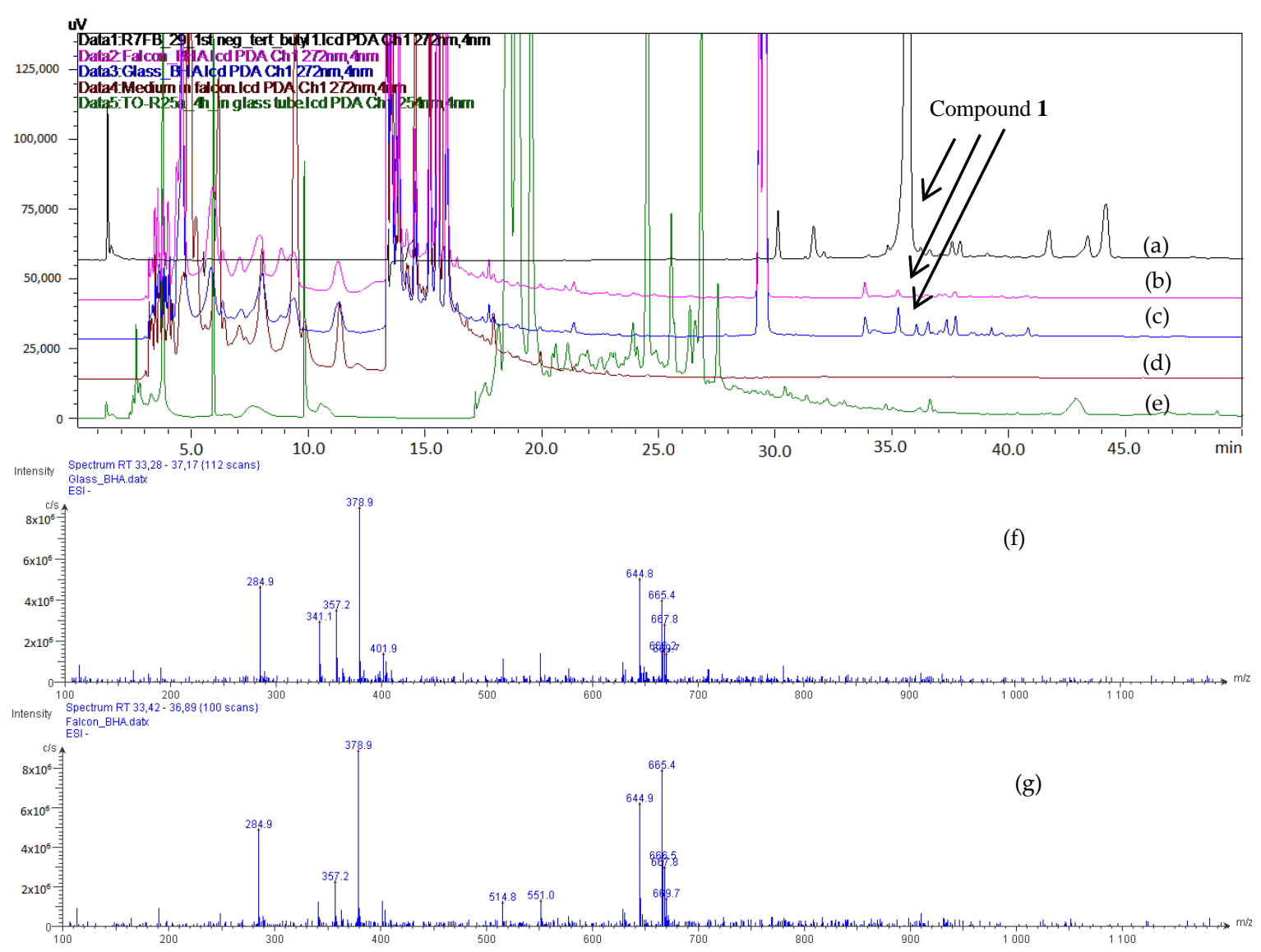

Figure 5. HPLC chromatograms of Compound 1 (a), of the extracts from P. odorifer culture supplemented with butylated hydroxyanisole (BHA) in the culture flask (b), or in the glass Erlenmeyer flask (c), of medium in the culture flask (d), and of the Paenibacillus odorifer (P. odorifer) culture in the Erlenmeyer flask (e). Electrospray ionisation (ESI)-MS (-) spectra of extracts from the $P$ odorifer culture supplemented with BHA in the culture flask (f), or in the glass Erlenmeyer flask (g).

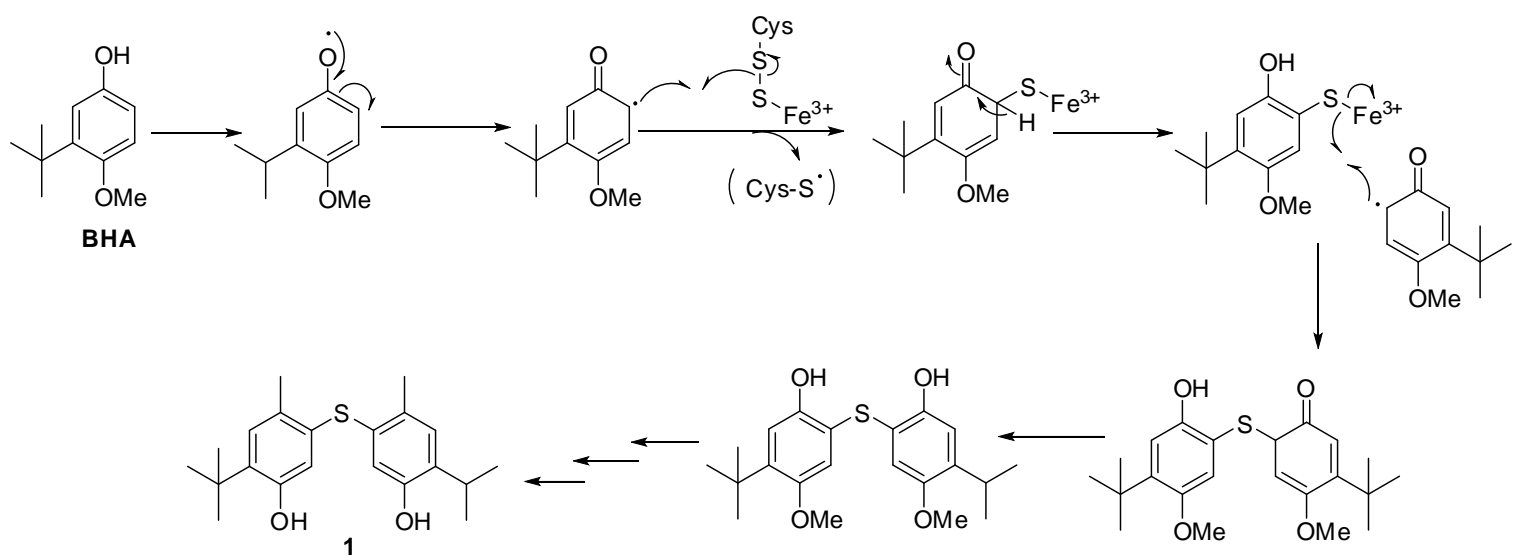

Figure 6. Putative biosynthetic pathway for Compound 1 from BHA supported by an iron-sulfur cluster protein with cysteine as a sulfur donor.

Compound 2, as with Compound 1, was isolated from the culture process using a culture flask in the pre-culture stage. In order to discover the origin of Compound 2, butylated hydroxytoluene (BHT), with its close structure to that of Compound 2, was used as a supplemented material during the culture of $P$. odorifer, put either in a culture flask or in an Erlenmeyer flask. The blank controls 
were the medium (without bacteria) in the culture flask and the culture of P. odorifer in the Erlenmeyer flask. The HPLC-MS data introduced in Figure 7 exhibited that Compound 2, with a retention time at $38 \mathrm{~min}$, was associated with an ion at $m / z 296$, which occurred in extracts from media supplemented with standard BHT in both the culture flask and the Erlenmeyer flask. This ion was detected in the MS spectrum of Compound 2 due to the hydrolysis of its ester group in LC-MS process. However, Compound 2 was not found in the medium put in the culture flask, but was found in the culture broth of P. odorifer in the Erlenmeyer flask. On the other hand, this compound was already reported in the literature [3] from Oakwood. Therefore, we propose that Compound 2 came from the bioconversion of $\mathrm{BHT}$, or as a natural metabolite from the culture of $P$. odorifer. Furthermore, our $P$. odorifer strain could be considered as a new example of tert-butylphenol-utilizing bacterium.
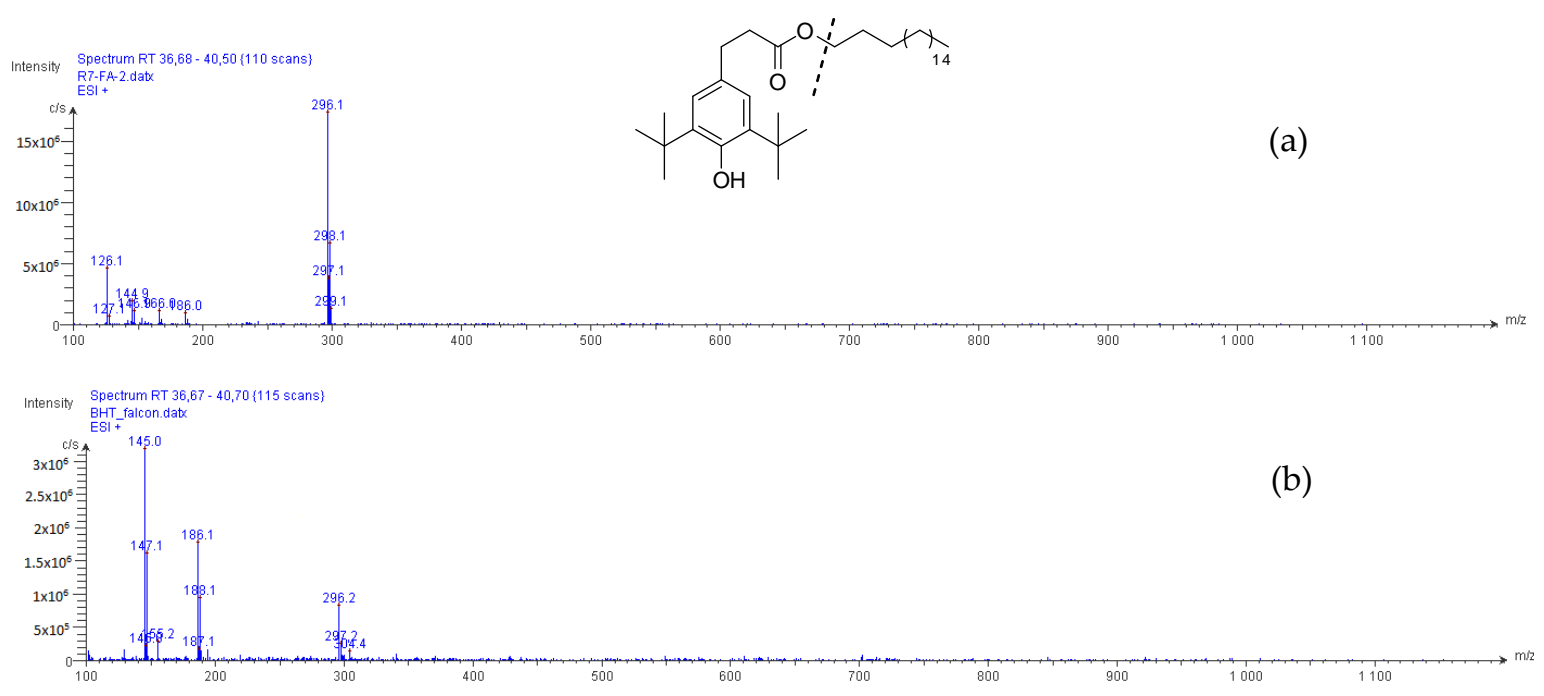

(c)

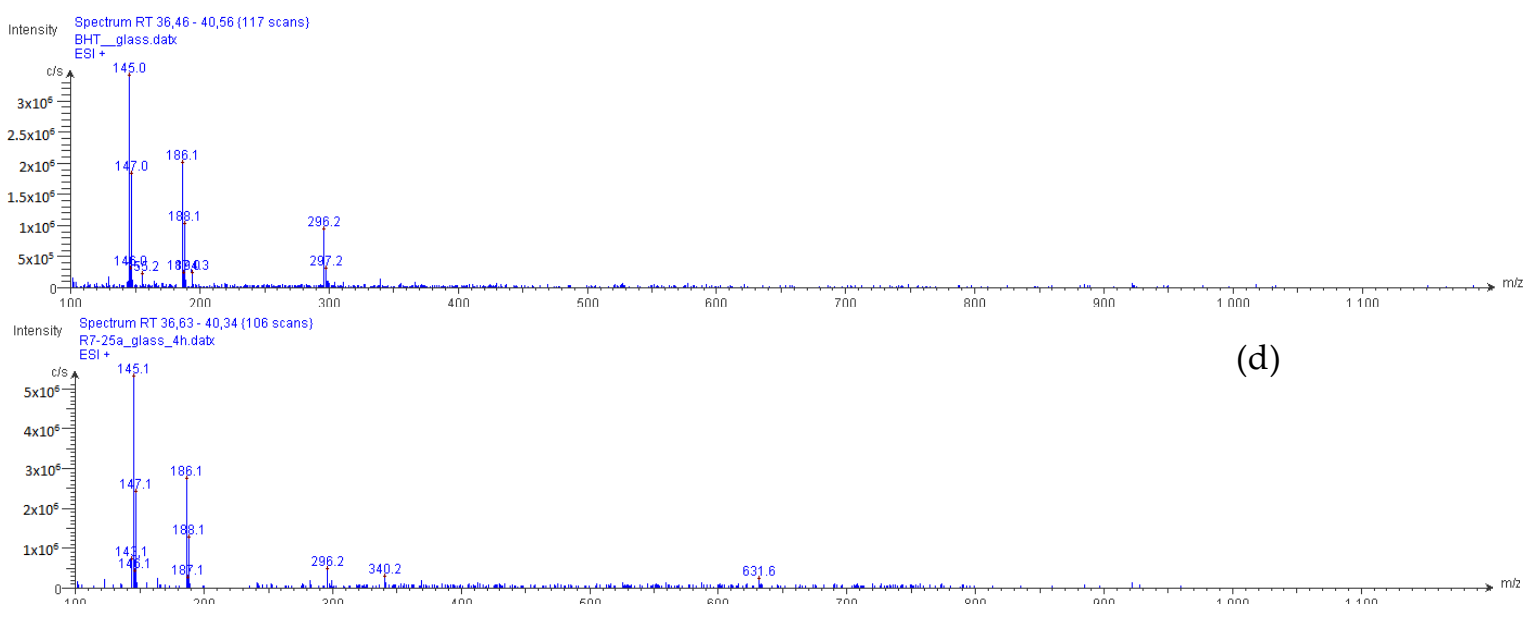

Figure 7. ESI-MS (+) spectra of Compound 2 (a), of the extracts from the culture supplemented with BHT in either the culture flask (b) or the Erlenmeyer flask (c), and of the culture of P. odorifer in the Erlenmeyer flask (d).

\subsection{Cytotoxic Activity}

The biological activities of Compounds $\mathbf{1}$ and $\mathbf{2}$ were tested using a 3-(4,5-dimethylthiazol-2-yl)-2,5-diphenyltetrazolium bromide (MTT) assay on HaCaT (human keratinocytes) and B16 (murine melanoma) cell lines (Table 3) [19]. Although neither compound showed activity significantly greater than the positive control (doxorubicin) against the two cell lines, Compound 
1 exhibited a significant half maximal inhibitory concentration $\left(\mathrm{IC}_{50}\right)$ on $\mathrm{B} 16(4.75 \mu \mathrm{M})$ and $\mathrm{HaCaT}$ $(8.38 \mu \mathrm{M})$, while Compound 2 was less active. Additionally, DNA damage assays, using $\gamma \mathrm{H} 2 \mathrm{AX}$ as a biomarker, were performed with Compound 1 on U2OS cells (Table 4). These cells are frequently used since they are sensitive to DNA damage. Although the compound was highly cytotoxic at $1 \mu \mathrm{M}$ (cell death $>90 \%$ ), no significant induction in $\gamma \mathrm{H} 2 \mathrm{AX}$ foci was observed at $1 \mu \mathrm{M}$ or $0.1 \mu \mathrm{M}$ within the nuclei, suggesting that no significant DNA damage was triggered compared to untreated cells. These results suggest that the cytotoxicity of Compound 1 was not driven by DNA damage.

Table 3. Cytotoxic assay of Compounds 1 and 2.

\begin{tabular}{ccc}
\hline \multirow{2}{*}{ Compound } & \multicolumn{2}{c}{$\mathrm{IC}_{\mathbf{5 0}}(\mu \mathrm{M})$} \\
\cline { 2 - 3 } & HaCaT & B16 \\
\hline $\mathbf{1}$ & 8.38 & 4.75 \\
$\mathbf{2}$ & $>377.4$ & $169.8 \pm 1$ \\
Doxorubicin & $0.096 \pm 0.009$ & $0.034 \pm 0.001$ \\
\hline
\end{tabular}

Table 4. DNA damage assay of Compound 1.

\begin{tabular}{cc}
\hline Concentration $(\mu \mathrm{M})$ & $\gamma$ H2AX Foci/Nuclei \\
\hline $\mathbf{0}$ & $12.9 \pm 0.4$ \\
$\mathbf{0 . 1}$ & $12.8 \pm 0.2$ \\
1 & $3.6 \pm 0.3$ \\
\hline
\end{tabular}

\section{Materials and Methods}

\subsection{General Experimental Procedures}

One-dimensional (1D) and two-dimensional (2D) NMR spectroscopic data were recorded in $\mathrm{MeOH}-d_{4}$ and $\mathrm{CDCl}_{3}$ on a Bruker DMX 300 spectrometer $\left(300 \mathrm{MHz}\left({ }^{1} \mathrm{H}\right)\right.$ and $75 \mathrm{MHz}\left({ }^{13} \mathrm{C}\right)$, Bruker BioSpin, Billerica, MA, USA). NMR spectroscopic data were processed using the MestRenoVa version 10.0 software (Mestrelab Research, S.L., Santiago de Compostela, Spain). HRMS measurements for exact mass determination were performed with a Q-Extractive Focus at the Centre Regional de Mesure Physique de l'Ouest (CRMPO), Rennes, France. Analytical HPLC and semi-preparative HPLC were performed on a $5-\mu \mathrm{m}$ Prevail $\mathrm{C}_{18}$ column $(250 \mathrm{~mm} \times 4.6 \mathrm{~mm}$ for the former, and $250 \mathrm{~mm} \times 10 \mathrm{~mm}$ for the later), GRACE, Columbia, MD, USA.

\subsection{Collection and Phylogenetic Analysis of PC-GYM-TO Strain}

The PC-GYM-TO strain was isolated from the crustose lichen, Rhizocarpon geographicum, collected in Brittany, France in February 2015. The strain was identified at Banyuls/mer Platform (L. Intertaglia) as Paenibacillus odorifer based on 16S ribosomal RNA (rRNA) gene sequence analysis (GenBank accession number AJ223990). A comparative BLAST similarities search of the 16S rRNA gene sequence gave a $98.46 \%$ similarity to that of P. odorifer (Gene bank entry PODO_RS03805). After culture in GYM Streptomyces medium (containing $4 \mathrm{~g}$ of glucose (Sigma-Aldrich, St Louis, MO, USA), $4 \mathrm{~g}$ of yeast extract (Sigma-Aldrich, St Louis, MO, USA), $10 \mathrm{~g}$ of malt extract (Sigma-Aldrich, St Louis, MO, USA), $2 \mathrm{~g}$ of $\mathrm{CaCO}_{3}$ (Merck KGaA, St Frankfurter, Darmstadt, Germany), and $12 \mathrm{~g}$ of agar (Sigma-Aldrich, St Louis, MO, USA) in $1 \mathrm{~L})$, the bacterium was stored in a mixture of $47.5 \%(v / v)$ glycerol, $47.5 \%(v / v)$ $\mathrm{H}_{2} \mathrm{O}$, and $5 \%(v / v)$ DMSO at $-80{ }^{\circ} \mathrm{C}$ with a reference of PC-GYM-TO (CORINT collection).

\subsection{Cultivation and Extraction}

P. odorifer (strain PC-GYM-TO) was cultured on GYM Streptomyces medium agar (2 g of glucose, $4 \mathrm{~g}$ of yeast extract, $4 \mathrm{~g}$ of malt extract, $2 \mathrm{~g}$ of $\mathrm{CaCO}_{3}$, and $12 \mathrm{~g}$ of agar in $1 \mathrm{~L}$ at $\left.\mathrm{pH} 7\right)$. The inoculum was prepared by transferring one loop full of culture (PC-GYM-TO) from agar medium to a 250-mL culture 
flask, containing $50 \mathrm{~mL}$ of liquid GYM Streptomyces medium (2 $\mathrm{g}$ of glucose, $4 \mathrm{~g}$ of yeast extract, $4 \mathrm{~g}$ of malt extract, and $2 \mathrm{~g}$ of $\mathrm{CaCO}_{3}$ in $1 \mathrm{~L}$ at $\mathrm{pH}$ 7). The bacterium culture was grown at $25^{\circ} \mathrm{C}$ on a rotary shaker incubator at $120 \mathrm{rpm}$ for seven days. After seven days for pre-culture, $42 \mathrm{~mL}$ of bacterium culture was transferred into 14 Erlenmeyer flasks $(500 \mathrm{~mL}$ ), each containing $300 \mathrm{~mL}$ of liquid GYM Streptomyces medium. The fermentation culture was then incubated at $25^{\circ} \mathrm{C}$ with 120 -rpm shaking for seven days. After seven days of culture, the fermentation broth was collected and centrifuged at $3500 \mathrm{rpm}$, at $4{ }^{\circ} \mathrm{C}$ for $15 \mathrm{~min}$. After removal of the pellet, sterilized XAD-7-HP resin $(40 \mathrm{~g} / \mathrm{L})$ was added to the supernatant to absorb the organic products from the culture, and the resin was then shaken at $220 \mathrm{rpm}$ for $4 \mathrm{~h}$. The resin was filtered and de-adsorbed by a mixture of solvent acetone/ $\mathrm{MeOH}(50 / 50$, $v / v)$. This mixture of solvent was removed under reduced pressure; the resulting aqueous layer was extracted with ethyl acetate $(\mathrm{EtOAc} ; 3 \times 300 \mathrm{~mL})$. The EtOAc/solute extract was dried under vacuum to yield $439.5 \mathrm{mg}$ of organic extract from $4.0 \mathrm{~L}$ of the culture.

Supplementation assays: BHA was supplemented with a quantity of $0.1 \mathrm{mg}$ per $25 \mathrm{~mL}$ of liquid GYM Streptomyces medium at day zero of the culture to check the origin of isolated compounds.

\subsection{Purification and Isolation}

The organic extract ( $439.5 \mathrm{mg}$ ) from strain PC-GYM-TO, after biological assays, was subjected to flash chromatography with a 50-g SiOH Chromabond ${ }^{\circledR}$ Flash column, using a sequential mixture of solvent with increasing polarity from cyclohexane to dichloromethane, EtOAc, and $\mathrm{MeOH}$ for $4 \mathrm{~h}$ to furnish 14 fractions. Guided by HPLC analysis, the first fraction containing Compound 2 (FA, $39.6 \mathrm{mg}$ ) and the second fraction containing Compound 1 (FB, $46.6 \mathrm{mg}$ ) were purified with semi-preparative HPLC (using a Prevail ${ }^{\circledR} \mathrm{C}_{18}$ column with a gradient of $0 \%$ to $100 \% \mathrm{CH}_{3} \mathrm{OH}$ in $\mathrm{H}_{2} \mathrm{O}$ for $60 \mathrm{~min}$, and a flow rate of $2.5 \mathrm{~mL} / \mathrm{min})$ and preparative TLC to afford Compound $1(5.0 \mathrm{mg})$ and Compound 2 (5.9 mg), with yields of $1.25 \mathrm{mg} / \mathrm{L}$ and $1.5 \mathrm{mg} / \mathrm{L}$, respectively.

LC-MS was applied using a Prevail ${ }^{\circledR} \mathrm{C}_{18}$ column, with a gradient of $0 \%$ to $100 \% \mathrm{CH}_{3} \mathrm{CN}$ in $\mathrm{H}_{2} \mathrm{O}$ for $60 \mathrm{~min}$, a flow rate of $0.8 \mathrm{~mL} / \mathrm{min}$, a sample concentration of $1 \mathrm{mg} / \mathrm{mL}$, and an MS full range from 100-1200.

5,5'-Thiobis(2-tert-butyl-4-methylphenol) (Compound 1): white amorphous powder, retention time $=35.7 \mathrm{~min} ; \mathrm{R}_{\mathrm{f}}=0.45$ (chloroform $\left.100 \%\right) .{ }^{1} \mathrm{H} \mathrm{NMR}\left(300 \mathrm{MHz}, \mathrm{CDCl}_{3}\right)$ and ${ }^{13} \mathrm{C} \mathrm{NMR}(75 \mathrm{MHz}$, $\mathrm{CDCl}_{3}$ ) are described in Table 1. HRESIMS $\mathrm{m} / \mathrm{z} 357.1983[\mathrm{M}-\mathrm{H}]^{-}$(calculated for $\mathrm{C}_{22} \mathrm{H}_{29} \mathrm{O}_{2} \mathrm{~S}$, $\Delta=0 \mathrm{ppm})$.

Octadecyl 3-(3,5-di-tert-butyl-4-hydroxyphenyl)propanoate (Compound 2): while solid, retention time $=26.7 \mathrm{~min} .{ }^{1} \mathrm{H}$ NMR $\left(300 \mathrm{MHz}, \mathrm{CDCl}_{3}\right)$ and ${ }^{13} \mathrm{C} \mathrm{NMR}\left(75 \mathrm{MHz}, \mathrm{CDCl}_{3}\right)$ are described in Table 2. HRESIMS $m / z 553.4592[\mathrm{M}+\mathrm{Na}]^{+}$(calculated for $\mathrm{C}_{35} \mathrm{H}_{32} \mathrm{O}_{3} \mathrm{Na}$ ).

\subsection{Molecular Models and Dynamic Simulations}

The structures of Compound 1 and Santonox were built using the Yasara program and were parameterized for the Yamber3 force field following the automated AutoSMILE procedure [20]. Both geometries were optimized through the standardized minimization protocol of Yasara. Finally, to enhance the conformational space exploration available to the structures, molecular models were used as an initial point for molecular dynamics (MD) simulations. Each isomer was placed in an explicit chloroform solvent box and simulated under periodic boundary conditions at a constant temperature of $300 \mathrm{~K}$. Structures were relaxed during a 2-ns MD simulation and trajectories were collected at 1-ps intervals. Analyses of the MD trajectories (root-mean-square deviation (RMSD) and clustering) was performed using Gromacs tools [21].

\subsection{Cytotoxicity Assays}

The cytotoxic assays were performed on pure compounds (with a concentration for each sample as $40 \mathrm{mg} / \mathrm{mL}$ ) against $\mathrm{HaCaT}$ human keratinocytes and B16 murine melanoma cell lines as described in the literature [19]. HaCaT (2000 cells/well) and B16 (1800 cells/well) were cultivated in Roswell Park Memorial Institute RPMI 1640 medium supplemented with 5\% fetal calf serum (FCS) and antibiotics 
in an atmosphere of $5 \% \mathrm{CO}_{2}$ at $37^{\circ} \mathrm{C}$. After a 24 -h culture, the samples were added at different concentrations $(1,10,50,100$, and $200 \mu \mathrm{g} / \mathrm{mL})$ and each 96-well plate was continuously incubated at the same temperature and atmosphere as above. After a 48 -h culture, cell growth and viability were then measured at $540 \mathrm{~nm}$ using a 3-(4,5-dimethylthiazol-2-yl)-2,5-diphenyltetrazolium bromide (MTT) assay. Doxorubicin was used as a positive control. Each experiment was repeated three times.

\subsection{DNA Damage Assays}

U2OS cells were cultivated in Dulbecco's Modified Eagle's medium DMEM supplemented with 10\% fetal calf serum and antibiotics in an atmosphere of $5 \% \mathrm{CO}_{2}$ at $37^{\circ} \mathrm{C}$. The $\gamma \mathrm{H} 2 \mathrm{AX}$ staining was performed as previously described [22]. Images were acquired on an ArrayScan VTI high-content screening reader with a 320 lens (Thermo Scientific, Villebon sur Yvette, France). The images were analyzed using the Cell Profiler software (http:/ / www.cellprofiler.org, Broad Institute). For all analyses, raw data files were obtained with the total amount of Hoechst fluorescence and the total amount of $\gamma \mathrm{H} 2 \mathrm{AX}$ fluorescence. The number of $\gamma \mathrm{H} 2 \mathrm{AX}$ foci per nucleus is indicated for each condition in Table 4 with more than 3000 cells counted except for the $1 \mu \mathrm{M}$ concentration because of the high cytotoxicity.

\section{Conclusions}

In summary, two tert-butylphenol compounds were firstly isolated from the culture of a bacterium, P. odorifer, associated with the lichen, Rhizocarpon geographicum. Compound $\mathbf{1}$ displayed a symmetric structure including two units of BHA linked by a sulfur bond. This point can be explained by the fact that Compound 1 was putatively formed via the bioaccumulation of BHA from the culture flask used in the culture process, followed by the biotransformation of BHA into Compound 1 . Therefore, a putative biosynthesis pathway was proposed for this compound, and involved an iron-sulfur cluster protein with cysteine as a sulfur donor. Compound $\mathbf{1}$ exhibited a moderate cytotoxicity, making it promising for further investigation to determine its mechanism. The results also highlighted P. odorifer as a new case of tert-butylphenol-utilizing bacterium.

Supplementary Materials: Supplementary Materials are available online.

Author Contributions: S.T. and T.-B.-L.N. conceived and designed the experiments; T.-B.-L.N. performed the experiments; T.-B.-L.N. analyzed the data; I.R. realized the biological assays on HaCaT and B16; R.P. and L.C. designed and realized the assays on DNA damage; O.D. designed and realized the NOE calculations; S.F. ran NMR; T.-B.-L.N and S.T. wrote the paper.

Funding: This research received no external funding.

Acknowledgments: We sincerely thank D. Delmail for his help in the isolation of the strain P. odorifer from R. geographicum; P. Jehan, F. Lambert, and T. Delhaye for the mass spectrometer measurements; L. Intertaglia from Banyuls/mer Platform Bio2Mar for the identification of the strain; E. Poupon (Biocis, Paris Saclay) and J-P. Hurvois for a critical discussion about biosynthesis; P. Uriac for a discussion about NMR data; and J. Boustie for his recommendations in the writing. The Vietnamese government is gratefully acknowledged for the PhD grant of Thi-Bach-Le Nguyen.

Conflicts of Interest: The authors declare no conflict of interest.

\section{References}

1. Wang, Y.; Schnell, B.; Baumann, S.; Müller, R.; Begley, T.P. Biosynthesis of Branched Alkoxy Groups: Iterative Methyl Group Alkylation by a Cobalamin-Dependent Radical SAM Enzyme. J. Am. Chem. Soc. 2017, 139, 1742-1745. [CrossRef] [PubMed]

2. Bisel, P.; Al-Momani, L.; Müller, M. The tert-Butyl Group in Chemistry and Biology. Org. Biomol. Chem. 2008, 6, 2655-2665. [CrossRef] [PubMed]

3. Dembitsky, V.M. Natural Neo Acids and Neo Alkanes: Their Analogs and Derivatives. Lipids 2006, 41, 309-340. [CrossRef] [PubMed]

4. Luesch, H.; Yoshida, W.Y.; Moore, R.E.; Paul, V.J.; Corbett, T.H. Total Structure Determination of Apratoxin A, a Potent Novel Cytotoxin from the Marine Cyanobacterium Lyngbya majuscula. J. Am. Chem. Soc. 2001, 123, 5418-5423. [CrossRef] [PubMed] 
5. Lopanik, N.; Gustafson, K.R.; Lindquist, N. Structure of Bryostatin 20: A Symbiont-Produced Chemical Defense for Larvae of the Host Bryozoan, Bugula Neritina. J. Nat. Prod. 2004, 67, 1412-1414. [CrossRef] [PubMed]

6. Pereira, A.R.; Cao, Z.; Engene, N.; Soria-Mercado, I.E.; Murray, T.F.; Gerwick, W.H. Palmyrolide A, an Unusually Stabilized Neuroactive Macrolide from Palmyra Atoll Cyanobacteria. Org. Lett. 2010, 12, 4490-4493. [CrossRef] [PubMed]

7. Matthew, S.; Salvador, L.A.; Schupp, P.J.; Paul, V.J.; Luesch, H. Cytotoxic Halogenated Macrolides and Modified Peptides from the Apratoxin-Producing Marine Cyanobacterium Lyngbya bouillonii from Guam. J. Nat. Prod. 2010, 73, 1544-1552. [CrossRef] [PubMed]

8. Tidgewell, K.; Engene, N.; Byrum, T.; Media, J.; Doi, T.; Valeriote, F.A.; Gerwick, W.H. Evolved Diversification of a Modular Natural Product Pathway: Apratoxins F and G, Two Cytotoxic Cyclic Depsipeptides from a Palmyra Collection of Lyngbya bouillonii. ChemBioChem 2010, 11, 1458-1466. [CrossRef] [PubMed]

9. Toyama, T.; Momotani, N.; Ogata, Y.; Miyamori, Y.; Inoue, D.; Sei, K.; Mori, K.; Kikuchi, S.; Ike, M. Isolation and Characterization of 4-tert-Butylphenol-Utilizing Sphingobium fuliginis Strains from Phragmites australis Rhizosphere Sediment. Appl. Environ. Microbiol. 2010, 76, 6733-6740. [CrossRef] [PubMed]

10. Suzuki, M.T.; Parrot, D.; Berg, G.; Grube, M.; Tomasi, S. Lichens as Natural Sources of Biotechnologically Relevant Bacteria. Appl. Microbiol. Biotechnol. 2015, 100, 583-595. [CrossRef] [PubMed]

11. Varsha, K.K.; Devendra, L.; Shilpa, G.; Priya, S.; Pandey, A.; Nampoothiri, K.M. 2,4-Di-tert-Butyl Phenol as the Antifungal, Antioxidant Bioactive Purified from a Newly Isolated Lactococcus Sp. Int. J. Food Microbiol. 2015, 211, 44-50. [CrossRef] [PubMed]

12. Jaivel, N.; Uvarani, C.; Rajesh, R.; Velmurugan, D.; Marimuthu, P. Natural Occurrence of Organofluorine and Other Constituents from Streptomyces Sp. TC1. J. Nat. Prod. 2014, 77, 2-8. [CrossRef] [PubMed]

13. Belghit, S.; Driche, E.H.; Bijani, C.; Zitouni, A.; Sabaou, N.; Badji, B.; Mathieu, F. Activity of 2,4-Di-tert-Butylphenol Produced by a Strain of Streptomyces mutabilis Isolated from a Saharan Soil against Candida albicans and Other Pathogenic Fungi. J. Med. Mycol. 2016, 26, 160-169. [CrossRef] [PubMed]

14. Yang, C.Z.; Yaniger, S.I.; Jordan, V.C.; Klein, D.J.; Bittner, G.D. Most Plastic Products Release Estrogenic Chemicals: A Potential Health Problem That Can Be Solved. Environ. Health Perspect. 2011, 119, 989-996. [CrossRef] [PubMed]

15. Li, B.; Wang, Z.-W.; Lin, Q.-B.; Hu, C.-Y.; Su, Q.-Z.; Wu, Y.-M. Determination of Polymer Additives-Antioxidants, Ultraviolet Stabilizers, Plasticizers and Photoinitiators in Plastic Food Package by Accelerated Solvent Extraction Coupled with High-Performance Liquid Chromatography. J. Chromatogr. Sci. 2015, 53, 1026-1035. [CrossRef] [PubMed]

16. Babich, H. Butylated Hydroxytoluene (BHT): A Review. Environ. Res. 1982, 29, 1-29. [CrossRef]

17. Fontecave, M.; Ollagnier-de-Choudens, S.; Mulliez, E. Biological Radical Sulfur Insertion Reactions. Chem. Rev. 2003, 103, 2149-2166. [CrossRef] [PubMed]

18. Fontecave, M.; Py, B.; Ollagnier de Choudens, S.; Barras, F. From Iron and Cysteine to Iron-Sulfur Clusters: The Biogenesis Protein Machineries. EcoSal Plus 2008, 3, 1-24. [CrossRef] [PubMed]

19. Millot, M.; Tomasi, S.; Studzinska, E.; Rouaud, I.; Boustie, J. Cytotoxic Constituents of the Lichen Diploicia canescens. J. Nat. Prod. 2009, 72, 2177-2180. [CrossRef] [PubMed]

20. Krieger, E.; Darden, T.; Nabuurs, S.B.; Finkelstein, A.; Vriend, G. Making optimal use of empirical energy functions: Force-field parameterization in crystal space. Proteins 2004, 57, 678-683. [CrossRef] [PubMed]

21. Van-der-Spoel, D.; Lindahl, E.; Hess, B.; Groenhof, G.; Mark, A.E.; Berendsen, H.J. GROMACS: Fast, flexible, and free. J. Comput. Chem. 2005, 26, 1701-1718. [CrossRef] [PubMed]

22. Bigot, N.; Mouche, A.; Preti, M.; Loisel, S.; Renoud, M.L.; Le Guével, R.; Sensebé, L.; Tarte, K.; Pedeux, R. Hypoxia Differentially Modulates the Genomic Stability of Clinical-Grade ADSCs and BM-MSCs in Long-Term Culture. Stem Cells 2015, 33, 3608-3620. [CrossRef] [PubMed]

Sample Availability: Samples of the Compounds 1, 2 are available from the authors. 